\title{
ICT IN FUNCTION OF PROMOTING INNOVATION FOR REALIZATION OF COMPETITIVE ADVANTAGE IN THE REPUBLIC OF MACEDONIA
}

\author{
Milena Boshkoska Klisaroski \\ Ministry of Finance \\ Skopje, Republic of Macedonia \\ milenaboskoska@yahoo.com
}

\begin{abstract}
Apstrakt
It is very important for a country to be aware of its ICT application capacity in order to stimulate innovation, not only for statistical purposes, but also in terms of comparison with other countries and taking appropriate ICT expansion measures, which would improve innovation and the possibility for Macedonian companies to export abroad.

The aim of the research in this paper is to assess the barriers that may limit the ability of companies to innovate and to identify potential measures that will encourage them for more innovation. The survey was conducted in the period when the Republic of Macedonia is increasingly encouraging and supporting the innovation activity in the companies for achieving accelerated technological development, based on knowledge transfer, R\&D (research and development), ICT, and innovations that contribute to the creation of new jobs and economic growth and development, while improving the business environment for developing the competitiveness of companies. The obtained results of this research can be a guide when creating the innovative strategy in the Republic of Macedonia. In order to assess the tendency and the absorptive capacity for innovation in the Republic of Macedonia there is a need of information for the innovation activities used by companies.
\end{abstract}

Ključne riječi: ICT, innovation, company, R\&D.

\section{IKT U FUNKCIJI PROMOVISANJA INOVACIJA ZA OSTVARIVANJE KONKURENTSKE PREDNOSTI U REPUBLICI MAKEDONIJI}

\begin{abstract}
Važno je da svaka zemlja bude svjesna svojih kapaciteta za primjenu IKT-a koji će podsticati inovacije, ne samo u statističke svrhe, ali u smislu uporedivosti sa drugim zemljama i preduzimanje odgovarajućih mera za širenja IKT što bi poboljšao inovacije i mogućnost makedonskih kompanija da izvoze $\mathrm{u}$ inostranstvo.

Cilj istraživanja u ovom radu je procjena barijera koje mogu ograničiti sposobnost kompanija da inoviraju i identifikuju potencijalne mjere koje će ih ohrabriti za više inovacija. Istraživanje je sprovedeno u periodu kada Republika Makedonija sve više ohrabruje i podržava inovativne aktivnoste u preduzećima radi postizanja ubrzanog tehnološkog razvoja na osnovu prenosa znanja, istraživanja i razvoja (IR), IKT i inovacija, koje doprinose stvaranju novih radnih mesta i ekonomskog rasta i razvoja, uz unapređenje poslovnog okruženja za razvoj konkurentnosti preduzeća. Dobijeni rezultati ovog istraživanja mogu biti vodič u kreiranju inovativne strategije u Republici Makedoniji. Da bi se procenila tendencija i sposobnost apsorpcije za inovacije u Republici Makedoniji, potrebno je informisanje o inovacionim aktivnostima koje koriste kompanije.
\end{abstract}


ICT in function of promoting innovation for realization of competitive advantage in the republic of Macedonia

Key words: IKT, inovacije, preduzeća, IR

JEL codes: O00

\section{INTRODUCTION}

It is widely accepted that innovation is a key driver for growth of production and productivity. With the development of world economy, the process of innovation is becoming more significant. Globalization has led to dramatic increases in access to information and the emergence of new markets for the companies. This resulted in greater international competition and rise of new organizational forms in order to manage global supply chains. Knowledge is increasingly seen as a central instigator of economic growth and innovation, due to the advancement in ICT and the increasing information flow. However, it has to be completely analyzed how these factors influence innovation.

Economic theory and empirical studies have shown that innovation is among the key drivers of economic growth and development. Innovations may increase productivity and quality of products and services, making the companies more competitive.

\section{RESEARCH PROBLEM, METHOD AND SAMPLE}

The main research problem is ICT and its role in promoting innovation with particular emphasis on the application of innovations and the need to adopt proactive strategies, creating the necessary ambience and connectivity with ICT and information society in the Republic of Macedonia.

The research subject is focused on the question of interconnection between ICT and innovation in the Republic of Macedonia, and what the role of ICT in promoting innovations in the country is.

The research aim is to explore what is the role of ICT in promoting innovations in the Republic of Macedonia.

To accomplish the objectives of the study, data were collected by means of a selfadministered questionnaire, prepared in Google Docs. The questionnaire was sent randomly to 400 companies in the Republic of Macedonia, and response was received from 103 companies.

Regarding the structure, the online questionnaire contained questions in closed ended format and a 5-point Likert scale. The model of questions was based on the theory and methodology presented in the Oslo Manual.

The questionnaire contained an introduction and five sections with logically connected questions.

The introduction part was designed to gather basic information for the companies, including sections, number of employees, profit and ownership. The other five sections used questions for innovation activities of the company, innovation drivers and barriers, cooperation with others (cooperation between companies and public 
institutions, as well as between companies), measures to support innovation and ICT innovation in the company.

\section{EMPIRICAL REASERCH}

The data analysis was accomplished using IBM ${ }^{\circledR}$ SPSS Statistics ${ }^{\circledR}$ v20 statistical software. Three types of analyses were primarily conducted: the first one included descriptive data analysis; the second one was Pearson Chi-Square test for independence, whilst the third one was Correlation-Pearson Correlation Coefficients. Due to the scope of the research, in this paper we will show only the part representing the model of ICT and innovation approach and the Pearson correlation coefficient. In order to determine the most important factors of ICT and innovation (based on questions from the questionnaire and from the conducted analysis of the hypothetical framework), a model of ICT and innovation approach is proposed. The model will contribute to greater implementation of ICT and innovation in the Macedonian companies (Picture 1).

\section{Picture 1. Model of ICT and innovation approach}

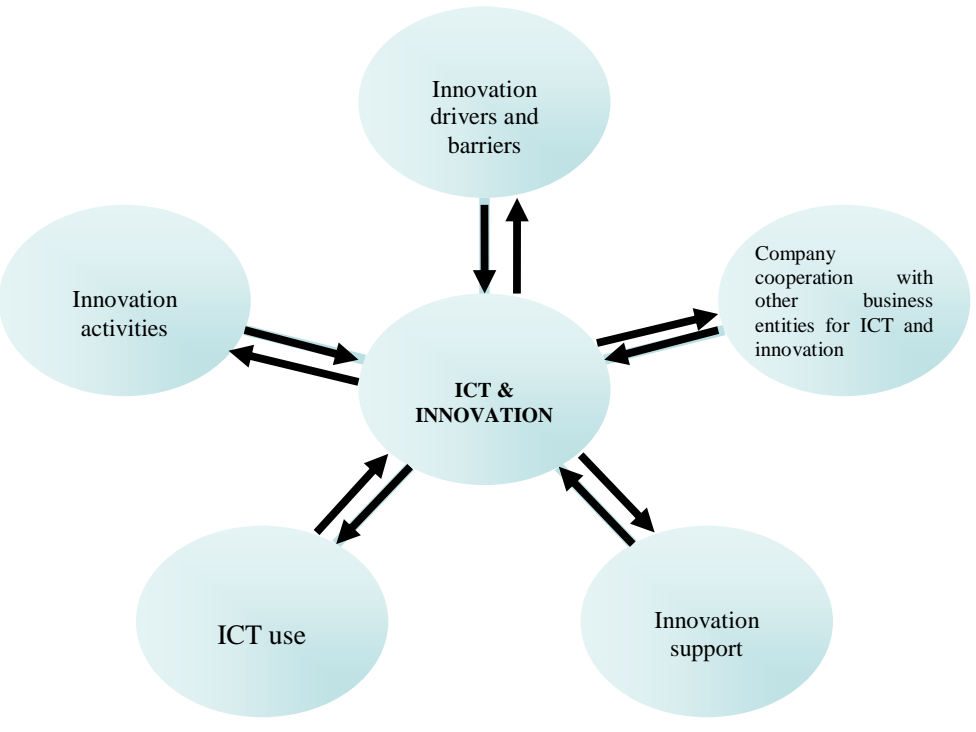

Source: Original research

For that purpose, five indexes were created for the five elements of the model. The five elements of this model are composed in a 21 sub indexes obtained through responses to the questions that measure the variables (Table 1).

\footnotetext{
${ }^{1}$ The research was conducted by the author of this paper; the research has been carried out as a part of the author's Doctoral dissertation.
} 
ICT in function of promoting innovation for realization of competitive advantage in the republic of Macedonia

In order to discover which variables have the greatest influence in the index, the correlation (Correlation), or Pearson Correlation Coefficients (Pearson Correlation Coefficients) is applied. In this way is determined the relationship between the variables of the model, as well as their strength and direction. The correlation is made for each variable (subindex) with the index and the subindex with the greatest value is selected. This means that the variable with the highest value has the highest relation to the index, i.e. it is the most important factor of the index.

Table 1. Indexes and subindexes

\begin{tabular}{|c|c|c|}
\hline $\mathrm{I}_{\mathrm{IA}}$ & $\begin{array}{l}\text { Innovation } \\
\text { activities }\end{array}$ & $\begin{array}{l}\mathrm{q}_{0} \text { Company innovations } \\
\mathrm{q}_{1} \text { Types of innovation } \\
\mathrm{q}_{2} \text { Number of accepted patent application } \\
\mathrm{q}_{3} \text { Profit increase } \\
\mathrm{q}_{4} \text { Employees in the company only for } \mathrm{R} \& \mathrm{D} \\
\mathrm{q}_{5} \text { Investing in innovative activities in the } \\
\text { company } \\
\mathrm{q}_{6} \text { Technological and non-technological } \\
\text { innovation }\end{array}$ \\
\hline $\mathrm{I}_{\text {IUB }}$ & $\begin{array}{l}\text { Innovation drivers } \\
\text { and barriers }\end{array}$ & $\begin{array}{l}\mathrm{w}_{1} \text { Innovation drivers in the company } \\
\mathrm{w}_{2} \text { Innovation barriers in the company }\end{array}$ \\
\hline $\mathrm{I}_{\mathrm{SDS}}$ & $\begin{array}{l}\text { Company } \\
\text { cooperation with } \\
\text { other business } \\
\text { entities for ICT } \\
\text { and innovation }\end{array}$ & $\begin{array}{l}\mathrm{p}_{1} \text { Company export } \\
\mathrm{p}_{2} \text { Company competition } \\
\mathrm{p}_{3} \text { Company cooperation with other subjects } \\
\mathrm{p}_{4} \text { Participation of the company in tenders for } \\
\text { public procurement }\end{array}$ \\
\hline $\mathrm{I}_{\mathrm{PI}}$ & $\begin{array}{l}\text { Innovation } \\
\text { support }\end{array}$ & $\begin{array}{l}\mathrm{s}_{1} \text { Use of standards } \\
\mathrm{s}_{2} \text { Difficulties finding domestic services for } \\
\text { certificates of standards } \\
\mathrm{s}_{3} \text { Government innovation policies }\end{array}$ \\
\hline $\mathrm{I}_{\mathrm{II}}$ & ICT use & $\begin{array}{l}\mathrm{d}_{1} \text { Company web page and profile on social } \\
\text { networks } \\
\mathrm{d}_{2} \text { Founds invested for ICT in the company } \\
\mathrm{d}_{3} \text { Use of ICT tools in the company } \\
\mathrm{d}_{4} \text { Use of ICT tools in different departments in } \\
\text { the company } \\
\mathrm{d}_{5} \text { Use of innovative software solutions in the } \\
\text { company }\end{array}$ \\
\hline
\end{tabular}

Source: Original research

Innovation activities index

This index consists seven variables: company innovations; types of innovation; number of accepted patent application; profit increase; employees in the company only for R\&D; investing in innovative activities in the company, and technological and non-technological innovation. 
Table 2. Correlation between variables

\begin{tabular}{|c|c|c|c|c|c|c|c|c|c|}
\hline & & $\mathrm{q}_{0}$ & $\mathrm{q}_{1}$ & $\mathrm{q}_{2}$ & $\mathrm{q}_{3}$ & $\mathrm{q}_{4}$ & $\mathrm{q}_{5}$ & $\mathrm{q}_{6}$ & $\mathrm{I}_{\mathrm{IA}}$ \\
\hline \multirow{4}{*}{$\mathrm{q}_{0}$} & Pearson Correlation & 1 & , 172 &, $595^{* *}$ & $(, 457)^{* *}$ & $(, 382)^{* *}$ & , 149 &, $430^{* *}$ & $416^{* *}$ \\
\hline & Sig. (2-tailed) & &, 083 &, 000 &, 000 &, 000 &, 133 &, 000 &, 000 \\
\hline & $\mathrm{N}$ & 103 & 103 & 103 & 103 & 103 & 103 & 103 & 103 \\
\hline & Pearson Correlation &, 172 & 1 & $(, 128)$ & $(, 079)$ & $(, 047)$ &, 127 &, $300^{* *}$ &, $439^{* *}$ \\
\hline \multirow[t]{3}{*}{$\mathrm{q}_{1}$} & Sig. (2-tailed) & ,083 & & ,197 & ,425 & ,637 & ,200 & ,002 &, 000 \\
\hline & $\mathrm{N}$ & 103 & 103 & 103 & 103 & 103 & 103 & 103 & 103 \\
\hline & Pearson Correlation &, $595^{* *}$ & $(, 128)$ & 1 & $(, 424)^{* *}$ & $(, 381)^{* *}$ & , 181 &, $385^{* *}$ &, $342^{* *}$ \\
\hline \multirow[t]{3}{*}{$\mathrm{q}_{2}$} & Sig. (2-tailed) &, 000 & , 197 & &, 000 &, 000 & ,068 &, 000 &, 000 \\
\hline & $\mathrm{N}$ & 103 & 103 & 103 & 103 & 103 & 103 & 103 & 103 \\
\hline & Pearson Correlation & $(, 457)^{* *}$ & $(, 079)$ & $(, 424)^{* *}$ & 1 &, $216^{*}$ & $(, 134)$ & $(, 092)$ & $(, 046)$ \\
\hline \multirow[t]{3}{*}{$\mathrm{q}_{3}$} & Sig. (2-tailed) &, 000 & ,425 & 000 & & 029 & ,178 &, 354 & ,646 \\
\hline & $\mathrm{N}$ & 103 & 103 & 103 & 103 & 103 & 103 & 103 & 103 \\
\hline & Pearson Correlation & $(, 382)^{* *}$ & $(, 047)$ & $(, 381)^{* *}$ & ,216* & 1 & $(, 035)$ & $(, 395)^{* *}$ & $(, 301)^{* *}$ \\
\hline \multirow[t]{3}{*}{$\mathrm{q}_{4}$} & Sig. (2-tailed) &, 000 & ,637 & ,000 & 029 & & ,723 &, 000 &, 002 \\
\hline & $\mathrm{N}$ & 103 & 103 & 103 & 103 & 103 & 103 & 103 & 103 \\
\hline & Pearson Correlation &, 149 &, 127 &, 181 & $(, 134)$ & $(, 035)$ & 1 &, $318^{* *}$ &, $584^{* *}$ \\
\hline \multirow[t]{3}{*}{$\mathrm{q}_{5}$} & Sig. (2-tailed) &, 133 & ,200 &, 068 &, 178 & ,723 & & ,001 & ,000 \\
\hline & $\mathrm{N}$ & 103 & 103 & 103 & 103 & 103 & 103 & 103 & 103 \\
\hline & Pearson Correlation &, $430^{* *}$ &, $300^{* *}$ &, $385^{* *}$ & $(, 092)$ & $(, 395)^{* *}$ &, $318^{* *}$ & 1 &, $935^{* *}$ \\
\hline \multirow{2}{*}{$\mathrm{q}_{6}$} & Sig. (2-tailed) &, 000 & ,002 &, 000 & ,354 &, 000 & ,001 & &, 000 \\
\hline & $\mathrm{N}$ & 103 & 103 & 103 & 103 & 103 & 103 & 103 & 103 \\
\hline & Pearson Correlation &, $416^{* *}$ &, $439^{* *}$ &, $342^{* *}$ & $(, 046)$ & $(, 301)^{* *}$ &, $584^{* *}$ &, $935^{* *}$ & 1 \\
\hline \multirow[t]{2}{*}{$\mathrm{I}_{\mathrm{IA}}$} & Sig. (2-tailed) &, 000 &, 000 & ,000 & ,646 & ,002 & ,000 & ,000 & \\
\hline & $\mathrm{N}$ & 103 & 103 & 103 & 103 & 103 & 103 & 103 & 103 \\
\hline
\end{tabular}

Source: Original research

In Table 2 it can be seen that there is a different correlation between the variables and the index. The medium correlation have variables $q 0(0.416), \mathrm{q} 1(0.439), \mathrm{q} 2(0.342)$ and $\mathrm{q} 4(-0.301)$, the small correlation has variable $\mathrm{q} 3(-0.046)$, and the strong correlation have variables q5(0.584) and q6(0.935). The strongest correlation has the variable q6, where $r=0.935, n=103$ and $p<0.05$. This suggests that the main factors of innovation activities are the technological and non-technological innovations of the company. The second most important factor is the investments in innovative activities in the company. The medium correlation has variables: company innovation, types of innovation, number of accepted patent application and employees in the company 
ICT in function of promoting innovation for realization of competitive advantage in the republic of Macedonia

only for R\&D. However, in spite of this, they have statistically significant correlation because $\mathrm{p}<0.05$. The small correlation has a variable profit increase and is not statistically significant $(\mathrm{p}>0.05)$.

When the company identifies its opportunities for innovation, then it focuses on determining in which innovation activities will invest annually. The company can invest in $\mathrm{R} \& \mathrm{D}$, machines, equipment and software; providing knowledge or in multiple activities simultaneously. However, factors with a medium correlation have a significant correlation with the innovation activities index.

Innovation drivers and barriers index

This index consists two variables: innovation drivers in the company, and innovation barriers in the company.

Table 3. Correlation between variables

\begin{tabular}{|c|c|c|c|c|}
\hline & & $\mathrm{w}_{1}$ & $\mathrm{~W}_{2}$ & $\mathrm{I}_{\text {IUB }}$ \\
\hline \multirow{4}{*}{$\mathrm{w}_{1}$} & Pearson Correlation & 1 &, $325^{* *}$ &, $596^{* *}$ \\
\hline & Sig. (2-tailed) & & ,001 & ,000 \\
\hline & $\mathrm{N}$ & 103 & 103 & 103 \\
\hline & Pearson Correlation &, $325^{* *}$ & 1 &, $953^{* *}$ \\
\hline \multirow[t]{3}{*}{$\mathrm{w}_{2}$} & Sig. (2-tailed) &, 001 & &, 000 \\
\hline & $\mathrm{N}$ & 103 & 103 & 103 \\
\hline & Pearson Correlation &, $596^{* *}$ & ,953** & 1 \\
\hline \multirow[t]{2}{*}{$\mathrm{I}_{\mathrm{IUB}}$} & Sig. (2-tailed) &, 000 &, 000 & \\
\hline & $\mathrm{N}$ & 103 & 103 & 103 \\
\hline
\end{tabular}

Source: Original research

In Table 3 we can see that variables have values greater than 0.05 that indicates a strong correlation between variables and the index IIUB.

The strongest correlation has variable $w 2$, where $r=0.953, n=103$ and $p<0.05$.

This suggests that the main factor of innovation drivers and barriers are the innovation barriers in the company. The second most important factor is the innovation drivers in the company, and they are statistically significant because $p<0.05$. Although they have the same statistical significance, however, there is the strongest correlation with barriers that does not allow companies to use ICTs and innovations. Most of the companies are focused on removing barriers that prevent them from innovating and developing their work, after that they will focus on consumer needs, suppliers, competition and their own initiative to innovate in their operations.

Company cooperation with other business entities for ICT and innovation index 
This index consists four variables: company export, company competition, company cooperation with other subjects, and participation of the company in tenders for public procurement.

Table 4. Correlation between variables

\begin{tabular}{|ll|r|r|r|r|r|}
\hline & & \multicolumn{1}{c|}{$\mathrm{p}_{1}$} & \multicolumn{1}{c|}{$\mathrm{p}_{2}$} & \multicolumn{1}{c|}{$\mathrm{p}_{3}$} & \multicolumn{1}{c|}{$\mathrm{p}_{4}$} & \multicolumn{1}{c}{$\mathrm{I}_{\mathrm{sds}}$} \\
\hline & Pearson Correlation & 1 &, $346^{* *}$ &, 173 &, 062 &, $502^{* *}$ \\
$\mathrm{p}_{1}$ lig. (2-tailed) & &, 000 &, 081 &, 533 &, 000 \\
& $\mathrm{~N}$ & 103 & 103 & 103 & 103 & 103 \\
& Pearson Correlation &, $346^{* *}$ & 1 &, $297^{* *}$ & $(, 092)$ &, $441^{* *}$ \\
$\mathrm{p}_{2}$ & Sig. (2-tailed) &, 000 & &, 002 &, 357 &, 000 \\
& $\mathrm{~N}$ & 103 & 103 & 103 & 103 & 103 \\
& Pearson Correlation &, 173 &, $297^{* *}$ & 1 & $(, 196)^{*}$ &, $934^{* *}$ \\
$\mathrm{p}_{3}$ & Sig. (2-tailed) &, 081 &, 002 & &, 047 &, 000 \\
& $\mathrm{~N}$ & 103 & 103 & 103 & 103 & 103 \\
& Pearson Correlation &, 062 & $(, 092)$ & $(, 196)^{*}$ & 1 & $(, 100)$ \\
$\mathrm{p}_{4}$ & Sig. (2-tailed) &, 533 &, 357 &, 047 & &, 314 \\
& $\mathrm{~N}$ & 103 & 103 & 103 & 103 & 103 \\
& Pearson Correlation &, $502^{* * *}$ &, $441^{* *}$ &, $934^{* *}$ & $(, 100)$ & 1 \\
$\mathrm{I}_{\mathrm{sds}}$ Sig. (2-tailed) &, 000 &, 000 &, 000 &, 314 & \\
& $\mathrm{~N}$ & 103 & 103 & 103 & 103 & 103 \\
\hline
\end{tabular}

Source: Original research

In Table 4 we can see different correlations between variables in the index. The medium correlation has the variable $\mathrm{p} 2(0.441)$, the small correlation has the variable $\mathrm{p} 4(-0.100)$, and the strong correlation has the variables $\mathrm{p} 1(0.502)$ and $\mathrm{p} 3(0.934)$. The strongest correlation has the variable $\mathrm{p} 3$, where $\mathrm{r}=0.934, \mathrm{n}=103$ and $\mathrm{p}<0.05$. This implies that the main cooperation factor of companies with other business subjects for ICT and innovations is the cooperation of the company with other subjects. The second most important factor is the company export, which has statistically significant correlation because $\mathrm{p}<0.05$. The medium correlation has a company competition variable and its statistically significant $\mathrm{p}<0.05$. The small correlation has a participation of the company in tenders for public procurement variable, and is not statistically significant $(\mathrm{p}>0.05)$.

It's beneficial to see with who the company cooperates with in the implementation of its innovative activities, whether with suppliers, universities, research institutes, consultants, etc. from the country or abroad, because according to that, the company chooses whether and where it will export its products and services. The level of competition on the market is the determined based on where the companies export.

Innovation support index

This index consists three variables: use of standards, difficulties finding domestic services for certificates of standards, and government innovation policies. 
ICT in function of promoting innovation for realization of competitive advantage in the republic of Macedonia

Table 5. Correlation between variables

\begin{tabular}{|c|c|c|c|c|c|}
\hline & & $\mathrm{s}_{1}$ & $\mathrm{~S}_{2}$ & $\mathrm{~S}_{3}$ & IPI \\
\hline & Pearson Correlation & 1 &, $350^{* *}$ & $(, 113)$ &, 050 \\
\hline \multirow[t]{3}{*}{$\mathrm{S}_{1}$} & Sig. (2-tailed) & &, 000 & 255 & ,618 \\
\hline & $\mathrm{N}$ & 103 & 103 & 103 & 103 \\
\hline & Pearson Correlation &, $350^{* *}$ & 1 & $(, 108)$ & ,068 \\
\hline & Sig. (2-tailed) &, 000 & & ,276 & ,498 \\
\hline & $\mathrm{N}$ & 103 & 103 & 103 & 103 \\
\hline & Pearson Correlation & $(, 113)$ & $(, 108)$ & 1 &, $979^{* *}$ \\
\hline & Sig. (2-tailed) & ,255 & ,276 & & ,000 \\
\hline & $\mathrm{N}$ & 103 & 103 & 103 & 103 \\
\hline & Pearson Correlation &, 050 & ,068 & ,979** & 1 \\
\hline & Sig. (2-tailed) & ,618 & ,498 &, 000 & \\
\hline & $\mathrm{N}$ & 103 & 103 & 103 & 103 \\
\hline
\end{tabular}

Source: Original research

In Table 5 we can see different correlations between variables and the index. The small correlation have the variables s1 (0.050) and s2 (0.068), and the strong correlation has the variable s3 (0.979). The strongest correlation has the variable s3, where $\mathrm{r}=0.979, \mathrm{n}=103$ and $\mathrm{p}<0.05$.

This suggests that the main innovation support factors are innovations provided by the government for the company. The other two variables have a small correlation and they are not statistically significant ( $p>0.05)$, which means they don't have effect on the index.

In other words, the application of quality standards and the ability to find domestic services for obtaining certification of standards has no connection with innovation support. The government of the Republic of Macedonia, with its reforms to ease growth and innovation, has already put the country on the path of reform.

ICT use index

This index consists five variables: company web page and profile on social networks, founds invested for ICT in the company, use of ICT tools in the company, use of ICT tools in different departments in the company, and use of innovative software solutions in the company.

Table 6. Correlation between variables

\begin{tabular}{|c|c|c|c|c|c|c|}
\hline & $\mathrm{d}_{1}$ & $\mathrm{~d}_{2}$ & $\mathrm{~d}_{3}$ & $\mathrm{~d}_{4}$ & $\mathrm{~d}_{5}$ & $\mathrm{I}_{\mathrm{II}}$ \\
\hline Pearson Correlation & 1 &, 117 & $(, 280)^{* *}$ &, 003 & ,097 & 126 \\
\hline $\mathrm{d}_{1}$ Sig. (2-tailed) & & 239 &, 004 & ,978 & ,331 & ,206 \\
\hline $\mathrm{N}$ & 103 & 103 & 103 & 103 & 103 & 103 \\
\hline Pearson Correlation &, 117 & 1 & $(, 265)^{* *}$ &, $454^{* *}$ &, $449^{* *}$ &, $571^{* *}$ \\
\hline $\mathrm{d}_{2}$ Sig. (2-tailed) & ,239 & & ,007 &, 000 & ,000 & ,000 \\
\hline $\mathrm{N}$ & 103 & 103 & 103 & 103 & 103 & 103 \\
\hline
\end{tabular}




\begin{tabular}{|c|c|c|c|c|c|c|c|}
\hline & Pea & $(, 280)^{* * *}$ & $(, 265)^{* *}$ & 1 & $\mid(, 040)$ & $(, 107)$ & \\
\hline & Sig. ( & ,004 & ,007 & & ,691 & ,283 & ,384 \\
\hline & $\mathrm{N}$ & 103 & 103 & 103 & 103 & 103 & 10 \\
\hline & & ,003 & ,454 & $(, 040)$ & 1 &, $573^{* *}$ &, $834^{\prime \prime}$ \\
\hline & Sig & 978 &, 00 & ,691 & &, 000 & \\
\hline & $\mathrm{N}$ & & & 103 & 103 & 103 & 10 \\
\hline & Pear & ,097, &, $449^{* * *}$ & $(, 107)$ &, $573^{* *}$ & 1 &, $922^{* *}$ \\
\hline & Sig. & ,331 & ,000 & ,283 & ,000 & &, 00 \\
\hline & $\mathrm{N}$ & & & 03 & & 103 & 10 \\
\hline & & ,126 &, $571^{* *}$ & $(, 087)$ &, $834^{* *}$ &, $922^{* *}$ & \\
\hline & Sig. ( & ,206 & ,000 & ,384 & ,000 & ,000 & \\
\hline & $\mathrm{N}$ & 103 & 103 & 03 & 03 & 103 & \\
\hline
\end{tabular}

Source: Original research

In Table 6 we can see different correlations between variables and the index. The small correlation has the variables $\mathrm{d} 1(0.126)$ and $\mathrm{d} 3(-0.087)$, and the strong correlation has the variables $\mathrm{d} 2(0.571), \mathrm{d} 4(0.834)$ and $\mathrm{d} 5(0.922)$. The strongest correlation has the variable $\mathrm{d} 5$, where $\mathrm{r}=0,922, \mathrm{n}=103$ and $\mathrm{p}<0.05$.

This shows that the main factor for ICT use in the company is the use of innovative software solutions.

The other one most important factor is use of ICT tools in different departments in the company and the third most important factor is founds invested for ICT in the company. Both factors have statistically significant correlation.

The small correlation has the variables: company web page and profile on social networks and use of ICT tools in the company, which are not statistically significant. ICT use in the companies means use of innovative software solutions (financial programs, electronic archives, e-commerce, etc.) in different departments in the companies, and that requires significant investment in financial assets on an annually basis. Although both variables have a small regression and are not statistically significant, company still needs them in order to get a better competitive position on the market.

Pearson Correlation Coefficients point the need of implementing of ICT in the companies as an innovative way that influences the company innovation.

The research is focused on quantitative analysis where the ICT model and the innovation approach have been set up, and determination of the variables that has the strongest influence on the elements of the model. Special emphasis is placed on the calculation of indexes. Most of the variables in the indexes have a strong correlation. Accordingly, with this research we get an answer for a couple of questions related to innovation and ICT in the Republic of Macedonia. In this regard, this part answers great deal of questions related to innovation and ICT in the Republic of Macedonia, which up until today is not completely elaborated.

The results of this study provide the following conclusions:

$>\quad$ By testing indexes, we can see which variables have the strongest impact on their value and on the model;

Empirical results show which variables have the strongest correlation on the model. In all indexes, most of the variables have a strong correlation which points on 
ICT in function of promoting innovation for realization of competitive advantage in the republic of Macedonia

a significant correlation between them. Also, indexes have a significant correlation with variables that has a medium correlation. Only variables with small correlation are not statistically significant.

$>$ In index innovation activities, the significant connection shows variables: investing in innovative activities in the company, technological and non-technological innovation. It refers to the conclusion that companies investing in innovative activities, such as: R\&D, machines, equipment and software; providing knowledge, etc; and recognize innovation opportunities are directed towards innovative operation mode and using the ICT tools in their operation.

Innovation drivers and innovation barriers in the company show significant connection with index innovation drivers and barriers. Innovation drivers represent the possibility to identify factors that is crucial for the company whether to invest or not in innovation. Also, an important factor is innovation barriers that determine which factors represent an important obstacle for the company to initiate innovations.

The correlation coefficient between variables in the index company cooperation with other business entities for ICT and innovation shows that subindex company cooperation with other subjects is most important for the company and has a great influence.

$>\quad$ In the index innovation support the most important subindex is government innovation policies. In the past few years the government provides funding for:

- Scientific research projects (national and international);

- Publishing;

- Scholarship for young researchers;

- Organization of national scientific conferences;

- Participation of scientific researchers in international conferences, seminars, congresses and symposiums;

- Study visits;

- Public institutions' programs;

- Purchase of foreign literature;

- Access to electronic databases.

That means that the government has a key role for stimulation the company to invest in innovation and use the ICT innovation. The government achieves stimulating by funding the companies and helping them in the realization of the aims abovementioned.

Founds invested in ICT, such as use of ICT tools in different departments and use of innovative software solutions in the company, are variables that have strongest influence in ICT use in the companies' index. Internet is the one that transferred companies from the traditional market to e-commerce and e-business. In order to participate in the new online business environment, companies have to make significant financial investments not only in the necessary technologies, but also in the processes and people that in indispensable for work. Creating value with ebusiness is one of the most important issues in making investment decisions in the company. 
From the research analyzes it can be concluded that the model of ICT and innovation approach is practical for use in the companies and represent a guide for implementation of ICT and innovation in the company;

In the long run, institutions, infrastructure, reducing macroeconomic stability and improving human capital show lower returns, the standard of living can only be improved if it is focused on technological innovation, or the use of ICTs. Innovation is especially important for developing countries for economies that are approaching knowledge and where the ability to apply new technologies is great. However, for developed countries in the innovation phase, this is not enough in order increase productivity. Companies in these countries must design advanced products so as to remain predominant on the world stage. This requires an environment that encourages innovation activities supported by both, the public and the private sector. This means that there are sufficient investments in R\&D and ICT, especially by private, high-quality scientific research institutions, with simultaneous cooperation between universities and industry supported by rigid protection of intellectual property.

\section{CONCLUSION}

A lot of innovation surveys, studies and analyzes are carried out on international and national level, and they have an impact on the business performance of companies in the sections in which they operate and on the country economy. The traditional approach for measuring innovation is based on a small number of individual indicators (for example, number of patents, investments in $\mathrm{R} \& \mathrm{D}$, number of published papers in scientific journals, etc.) for that purpose a number of simple and complex (composite) indicators in the world is developed, that directly or indirectly measure the various aspects of innovative activities and results at international, national and local levels. The modern approach for measuring innovation is based on the application of complex indicators that unite a greater number of individual innovation parameters. The use of complex indicators reflects the time and level of development of the modern economy and is the result of changes in society that aim to achieve a higher level of knowledge, skills and competences. In this way, there are is a need for more complete and real way to measure the impact of the innovative activities that exist in modern economy and society.

This paper research is an attempt to determine the role of ICT in the promotion of innovation in the Republic of Macedonia. But it is not always possible to make certain predictions related to this issue for the trends of the future movement. That is why the need for continuous annual research is imposed, which will be an excellent basis for further forecasts, but also for comparisons of the Republic of Macedonia with other European countries. On the other hand, the role and influence that ICT has on innovation is an inexhaustible source of research and an opportunity for their application implementing.

\section{REFERENCES}

1. Canberra Manual (1995) „Manual on the measurement of human resources devoted to S\&T“, OECD and ECSC-EC-EAEC, Brussels, Luxembourg 
ICT in function of promoting innovation for realization of competitive advantage in the republic of Macedonia

2. Lopez-Claros, A., and Mata, Y. (2011),,The innovation for development report 20102011: Innovation as a driver of productivity and economic growth“,New York, Palgrave MacMillan,

3. OECD \& European commission, „Handbook on Constructing composite Indicators: methodology and user guide“, OECD publications, France, 2008

4. OECD (2000) ,A New Economy? The Changing Role of Innovation and Information Technology in Growth“, OECD Publications, France,

5. Oslo Manual (2005) „The Measurement of Scientific and Technological Activities“, A joint publication of OECD and Eurostat, Third edition,

6. Oslo Manual (2005) 3rd Ed., „Guidelines for Collecting and Interpreting Innovation Data“, OECD Publications, Paris,

\section{ZAKLJUČAK}

Veliki broj istraživanja, studija i analiza koje se sprovode na međunarodnom i nacionalnom nivou a se odnose na inovacije, određuju uticaj inovacija na poslovne rezultate preduzeća, na sektore kose bave sa time i na ekonomiju u celini. Tradicionalni pristup merenja inovacija se zasnova na malom broju pojedinačnih indikatora (na primer, broj patenata, ulaganja u istraživanje i razvoj, broj radova objavljenih u naučnim časopisima, itd), za tu cilj su se razvile mnoge jednostavne i kompleksne (kompozitni) indikatora u svetu, koje direktno ili indirektno mere različite aspekte inovativnih aktivnosti i rezultate na međunacionalnom, nacionalnom i lokalnom nivou. Savremeni pristup merenja inovacija se zasniva na primeni složenih indikatora koji ujedinjuju veći broj individualnih inovacionih parametara. Upotreba složenih indikatora je rezultat na vreme i nivo razvoja moderne ekonomije kako i promene u društvu, koje imaju za cilj da se postigne viši nivo znanja, vještina i kompetencija. Tako se pojavila potreba za potpun i realističan način da se izmeri uticaj inovativnih aktivnosti koje postoje u savremenoj ekonomiji i društvu.

Istraživacki cilj u ovom radu je pokušaj u definisanja uloge IKT u promociji inovacija u zemlji. No uvek nije moguće napraviti određene prognoze za prilagođavanje na novonastalim tržišnim trendovima. Na osnovu toga, se stvara potreba za stalnom godišnjem istraživanje koje će predstavljati odličnu osnovu za dalje prognoze, kao i za poređenja između Republike Makedonije i drugih evropskih zemalja tokom vremena. S druge strane, uloga i uticaj koji IKT-a ima nad inovacija je neiscrpan izvor za istraživanje i mogućnost njihove primene. 